\title{
Mixtures of Pseudomonas putida CECT 5279 cells of different ages: Optimization as biodesulfurization catalyst
}

\author{
J. Calzada, A. Alcon, V.E. Santos*, F. Garcia-Ochoa \\ Departamento de Ingenieria Quimica, Facultad de Ciencias Quimicas, Universidad Complutense de Madrid, 28040 Madrid, Spain
}

\section{A R T I C L E I N F O}

\section{Article history:}

Received 16 December 2010

Received in revised form 9 February 2011

Accepted 25 February 2011

\section{Keywords:}

Biodesulfurization

Pseudomonas putida CECT 5279

Complex biocatalyst

Biocatalyst formulation

DBT desulfurization

Dibenzothiophene

$4 \mathrm{~S}$ route

\begin{abstract}
A B S T R A C T
Sulfur content in fossil fuels is known to be the most important anthropogenic cause of sulfur oxide emissions to the atmosphere. In order to avoid health, environmental and technical problems caused by this compound, legislation imposes restrictive limitations to fuel sulfur content. Biodesulfurization (BDS) can become a complementary technology to hydrodesulfurization (HDS) to face this situation. Pseudomonas putida CECT 5279 is a genetically modified microorganism which can act as a desulfurizing biocatalyst. This microorganism has the ability of performing the metabolic $4 \mathrm{~S}$ pathway from Rhodococcus erythropolis IGTS8, in order to desulfurize DBT, as a model compound. Maximum in vivo activities of monooxygenase enzymes (DszA and DszC) are shown when late exponential growth phase is reached $(23 \mathrm{~h})$, while desulfinase enzyme DszB presents a maximum activity during the early exponential growth phase $(5 \mathrm{~h})$, as previously reported [1]. Also, it has been proved that the combined utilization of these two cell ages yields excellent results when used as biocatalyst for desulfurization [2]. The aim of this work is to optimize the ratio and total biomass concentration of both $5 \mathrm{~h}$ and $23 \mathrm{~h}$ growth time cells in a complex biocatalyst for desulfurization by performing resting cells biodesulfurization assays using dibenzothiophene (DBT) as sulfur model compound. The best combination of cells was determined aiming for the highest desulfurization in the shortest time of operation while investing the minimum concentration of biomass. A particular cell mixture, containing $66.7 \%$ of $23 \mathrm{~h}$ growth time cells, was found to work as the most effective desulfurization biocatalyst.
\end{abstract}

(c) 2011 Published by Elsevier Ltd.

\section{Introduction}

Current living standards require a high demand of energy coming from fossil fuels $[3,4]$. Combustion of oil causes the emission of sulfur oxides, which are responsible for many well known environmental, health and material stability problems [5-7]. Quite restrictive legal limitations have been imposed in the European Union [8], United States [9] and other countries such as Japan and Canada [5] in order to avoid these noxious effects. Such low limits (around 10 ppm of sulfur $[5,8,9]$ ) can be achieved by employing different proposed technologies [10]. Among them, hydrodesulfurization (HDS) is the most widely employed. However, there is a group of aromatic sulfur-containing compounds, such as 4- and 4,6-alkyl DBT, and polyaromatic sulfur heterocycles, which show resistance to be completely removed by conventional HDS processes [11]. Improving sulfur compound removal involves not only the use of more severe conditions of pressure and temperature

\footnotetext{
* Corresponding author at: Departamento de Ingenieria Quimica, Facultad de Ciencias Quimicas, Universidad Complutense de Madrid, Ciudad Universitaria s/n 28040 Madrid, Spain. Tel.: +34 913944179; fax: +34 913944179

E-mail address: vesantos@quim.ucm.es (V.E. Santos).
}

which can alter fuel final characteristics, but also the increase of investment in order to develop better and poisoning resistant catalysts $[10,11]$. Therefore, techniques involving milder operation conditions and reducing $\mathrm{CO}_{2}$ production need to be studied and developed [5].

Biodesulfurization (BDS) is one of the emerging technologies which can satisfy many of the requirements to confront the disadvantages of conventional HDS. Such biological treatment involves the use of microorganisms, their enzymes or cellular extracts as catalysts in order to remove sulfur present in fuels [12-16]. BDS is based on the degradation of sulfur aromatic molecules through a process where mild conditions of temperature and pressure are employed. Under these premises, BDS technology can succeed in reducing energy waste [5], greenhouse gases exhausts and capital investment [16-19]. This technique is not proposed as an alternative process to HDS, but instead, as a technology that, when added to a previous HDS process could complement it and succeed in obtaining high quality fuels, while respecting existing regulations. BDS offers a high selectivity technique due to the use of biocatalytic enzymatic systems with the ability of reducing the generation of undesirable byproducts $[15,16,20]$. One of the strengths of biological desulfurization is the possibility of hardly alter the treated fuel because of the employ of microorganisms following 
sulfur selective pathways. Such biocatalysts avoid C-C bond cleavage helping to maintain the final properties of the fuel $[5,15,16,21]$. Rhodococcus erythropolis IGTS8 belongs to this group of microorganisms and it has become the most widely employed desulfurizing biocatalyst. This strain is able to complete an oxidative and nondestructive metabolic route $[5,10,16,22-24]$ which is called $4 \mathrm{~S}$ route, due to the transformation of dibenzothiophene (DBT) into a sulfur-free molecule, 2,2'-hydroxybiphenil (HBP), through four in series reactions $[25,26]$. DBT and its alkylated forms are employed as model compounds in desulfurization studies because of their abundance in fossil fuels $[15,27]$ and particularly in heavier oil distillates $[28,29]$. These compounds present a special resistance to be removed by conventional HDS processes [12,13,29], thus, the oil after HDS usually contains DBT and its alkylated derivatives.

Current knowledge about $4 \mathrm{~S}$ route includes information about both genes and enzymes needed for this transformation [25,30]. Two monoxygenases, DszC and DszA, and a desulfinase, DszB, participate in the conversion of DBT into HBP. Flavin-dependent monooxygenases DszC catalyses the first two steps of DBT oxidation into dibenzothiophene-5-oxide (DBTO) and consecutively into dibenzothiophene-5,5-dioxide (DBTO2). Monooxygenase DszA catalyses the transformation of $\mathrm{DBTO}_{2}$ into 2-(2-hydroxybiphenyl)benzenesulfinate (HBPS). The third enzyme involved in $4 \mathrm{~S}$ route, desulfinase DszB, catalyses the last step of $4 \mathrm{~S}$ route, which involves the conversion of HBPS into the final product, HBP [25,30,31]. Development of BDS in order to become an industrial scale process requires improving not only the process itself (through reactor design, optimization of operation conditions and down stream operation) [13], but the characteristics of biocatalysts as well $[5,13,15,16,32,33]$. Great effort has been made aiming for higher biodesulfurization activity or designing a recombinant biocatalyst with a stable activity $[5,22,29,30,34,35]$. The interest of obtaining recombinant bacteria deals with over-expressing the genes of the $4 \mathrm{~S}$ route $[30,36,37]$. Therefore, many mutants have been constructed in Pseudomonas sp. [38-40] and other bacteria [41-45].

The microorganism employed in this work as biocatalyst is Pseudomonas putida CECT 5279, which is a genetically modified bacterium with the ability of expressing the $4 \mathrm{~S}$ pathway owing to the fact that this strain carries the genes $d s z A B C$ from Rhodococcus erythtropolis IGTS8, and a flavin-oxydo-reductase from E. coli (hpaC) $[46,47]$. Previous works allow compiling information about the behavior of this bacterial strain when it is employed as a desulfurizing biocatalyst. On one hand, a maximum desulfurizing capability is observed when cells collected at around $9 \mathrm{~h}$ of growth time are employed for DBT desulfurization in resting cell conditions $[48,49]$. A deep study on BDS of DBT using resting cells could prove that the transport of all $4 \mathrm{~S}$ route intermediates across the cell membrane is not a mass transport controlling resistance [50], and that neither the intracellular concentrations of reducing cofactors nor the NADH dependent reductase $\mathrm{HpaC}$ have influence on the desulfurization rate [50]. Based on these data, in vivo enzymatic activities of DszA, DszB and DszC could be studied along the growth curve of Pseudomonas putida CECT 5279 [1]. This study proved the presence of maximum activities of both flavin-dependent monooxygenases, DszC and DszA, at around $23 \mathrm{~h}$ of growth time, and a maximum activity for the desulfinase DszB, reached at around $5 \mathrm{~h}$ of growth time of Pseudomonas putida CECT 5279. These different patterns of expression of monooxygenases DszA and DszC and desulfinase DszB throughout growth time, were found to explain the behavior of cells collected at $9 \mathrm{~h}$ of growth time [1].

The aim of this work is testing different complex biocatalysts composed by cells of Pseudomonas putida CECT 5279, collected at growth times of 5 and $23 \mathrm{~h}$, varying the total biomass concentration and the proportion of the aforementioned cell ages. The results obtained in resting cell assays are compared to the response given by a simple biocatalyst previously optimized $[48,49]$, formulated only using $9 \mathrm{~h}$ cells, employing analogous total biomass concentrations. Specific conversion rate is the parameter used to select one of the proposed cell mixtures as an adequate complex biocatalyst pursuing the highest DBT conversion into HBP, the minimum time of operation and the lowest biomass investment.

\section{Materials and methods}

\subsection{Chemicals}

Dibenzothiophene was purchased from Aldrich, HEPES buffer and IPTG (isopropyl- $\beta$-D-galactopyranoside) were purchased from Sigma. Deionized water (resistance $=18.2 \Omega$ ) was used to prepare all media and stock solutions.

\subsection{Microorganism}

Pseudomonas putida CECT 5279 was the bacterium used as biocatalyst. It was supplied by the Biological Research Center (CIB-CSIC-Madrid, Spain) [38]. Cultures were concentrated, resuspended with a glycerol in saline serum (50\%) solution and conserved at $-80^{\circ} \mathrm{C}$.

\subsection{Biocatalyst production}

In order to obtain comparative experimental results, a previously described standardized procedure was employed $[48,49]$. Frozen stocks were used as inocula and grown in Luria-Bertani (LB) rich medium, containing $1 \%$ tryptone, $0.5 \%$ yeast extract and $1 \% \mathrm{NaCl}$, in Erlenmeyer flasks, and maintained at $210 \mathrm{rpm}$ and $30^{\circ} \mathrm{C}$ in an orbital shaker for $12 \mathrm{~h}$. A second growth was accomplished in LB medium under the same conditions for $4 \mathrm{~h}$, after inoculating bacteria from the previous culture. These cells were employed as inoculum in a $2 \mathrm{~L}$ commercial bioreactor (BIOSTAT B, Braun Biotech). Biocatalyst production was carried out using basal salt medium (BSM) containing $\mathrm{NaH}_{2} \mathrm{PO}_{4} \cdot \mathrm{H}_{2} \mathrm{O}, 4 \mathrm{~g} / \mathrm{L} ; \mathrm{K}_{2} \mathrm{HPO}_{4}, 4 \mathrm{~g} / \mathrm{L} ; \mathrm{MgCl}_{2} \cdot 6 \mathrm{H}_{2} \mathrm{O}, 0.0245 \mathrm{~g} / \mathrm{L} ; \mathrm{CaCl}_{2} \cdot 2 \mathrm{H}_{2} \mathrm{O}$ $0.001 \mathrm{~g} / \mathrm{L} ; \mathrm{MgSO}_{4}, 2 \mathrm{mM}$; glycerine, $2 \% ; \mathrm{FeCl}_{3} \cdot 6 \mathrm{H}_{2} \mathrm{O}, 0.001 \mathrm{~g} / \mathrm{L} ; \mathrm{NH}_{4} \mathrm{Cl}, 2 \mathrm{~g} / \mathrm{L}$. IPTG $(0.2 \mathrm{mM})$ and tetracycline $(25 \mu \mathrm{g} / \mathrm{mL})$, as explained in previous works [48]. The carbon source employed in these experiments was glutamic acid $20 \mathrm{~g} / \mathrm{L}[48,49]$. Operational conditions employed were: $1 \mathrm{~L} / \mathrm{L} / \mathrm{min}$ of aeration, $200 \mathrm{rpm}$ of stirrer speed and $30^{\circ} \mathrm{C}$ of temperature [48,49]. Since it has been shown in a previous work that Pseudomonas putida CECT 5279 yields higher DBT conversion when glutamic acid is used as carbon source in a non-buffered medium [49], initial pH was adjusted but not controlled during the process. Cells were collected at selected growth times $(5,9$ and $23 \mathrm{~h})$ in order to execute biodesulfurization assays using different biocatalyst formulations as previously exposed. Under these conditions, average values of biomass concentration reached after 5 and $23 \mathrm{~h}$ of growth time were, respectively, 0.75 and $2.1 \mathrm{gDCW} / \mathrm{L}$.

\subsection{Resting cell assays}

Resting cell desulfurization assays were carried out by using cells previously collected at selected growth times and conserved at $-18^{\circ} \mathrm{C}$, after centrifugation and resuspension in a glycerol-saline (1:1) solution [1]. These cells were suspended in a $100 \mathrm{~mL}$ Erlenmeyer flask, containing $16 \mathrm{~mL}$ of $50 \mathrm{mM}$ HEPES buffer ( $\mathrm{pH} 8.0$ ) and $25 \mu \mathrm{M}$ DBT, varying total biomass concentrations from 0.7 to $4.2 \mathrm{gDCW} / \mathrm{L}$. Desulfurization was performed at $30^{\circ} \mathrm{C}, 210 \mathrm{rpm}$ in orbital shaker for $180 \mathrm{~min}$. Samples of $0.5 \mathrm{~mL}$ were collected periodically; samples were afterwards mixed with $0.5 \mathrm{~mL}$ of acetonitrile in Eppendorf tubes in order to stop the reactions and then centrifuged at $14,000 \times g$ for $9 \mathrm{~min}$. Finally, $0.75 \mathrm{~mL}$ of the supernatant was withdrawn for analysis.

\subsection{Analytical methods}

Biomass concentration was determined as optical density at $600 \mathrm{~nm}$ (OD600) measured in a Shimadzu UV-visible spectra-photometer (model UV-1603). HPLC was employed to analyze DBT and HBP. Samples were acidified by using $\mathrm{HCl}$ and then analyzed using a C-18 column (Kromasil $150 \mathrm{~mm} \times 4.6 \mathrm{~mm}, 5 \mu \mathrm{m}$ particles). The mobile phase was an initial mixture acetonitrile/water (50/50) at $1 \mathrm{~mL} / \mathrm{min}$ initia flow rate. Peaks were monitored at different wavelengths ( $206 \mathrm{~nm} \mathrm{HBP}$ and $234 \mathrm{~nm}$ for DBT). Calibrations were performed using commercial and highly purified DBT and HBP chemicals.

\subsection{Evaluation of tested biocatalysts}

Performance and effectiveness of proposed biocatalysts used in desulfurization assays were evaluated using the following parameters:

Maximum percentage of desulfurization $\left(X_{\mathrm{BDS}}^{\mathrm{MAX}}\right)$, this parameter indicates the maximum desulfurizing capability of cells obtained during the resting cell assay, according to the following equation:

$X_{\mathrm{BDS}}^{\mathrm{MAX}}=\frac{C_{\mathrm{HBP}}^{\mathrm{MAX}}}{C_{\mathrm{DBT}}^{0}} \times 100$ 
where $C_{\mathrm{DBT}}^{0}$ is the initial concentration of DBT used to perform the resting cell assay $(25 \mu \mathrm{M})$ and $C_{\mathrm{HBP}}^{\mathrm{MAX}}$ is the maximum HBP concentration obtained during the time employed in the resting cell assay.

- Time for maximum biodesulfurization $\left(t_{\mathrm{BDS}}^{\max }\right)$, indicates the time at which the maximum percentage of biodesulfurization has been reached in the resting cells assay. - Initial DBT removal rate, $R_{\mathrm{DBT}}^{0}$, which shows the initial rate of DBT transformation. It is calculated by applying differential method over the evolution of DBT concentration throughout time in order to estimate the value of DBT removal rate at time zero, according to the following expression:

$R_{\mathrm{DBT}}^{0}=\left.\frac{d C_{\mathrm{DBT}}}{d t}\right|_{t=0}$

- Maximum productivity, $P_{\mathrm{BDS}}^{\mathrm{MAX}}$, which relates maximum percentage of desulfurization to the time needed for this conversion as follows:

$P_{\mathrm{BDS}}^{\max }=\frac{X_{\mathrm{BDS}}^{\mathrm{MAX}}}{t_{\mathrm{BDS}}}$

- Specific conversion rate, $E$, which regards the performance of each tested biocatalyst. It relates $X_{\mathrm{BDS}}^{\mathrm{MAX}}$, concentration of biomass, $C_{X}$ and the time needed for this maximum achieved conversion, according to:

$E=\frac{X_{\mathrm{BDS}}^{\mathrm{MAX}}}{t_{\mathrm{BDS}} C_{\max } C_{X}}$

According to the parameters discussed above, the formulation for this complex biocatalyst has been selected. This selection takes into account the highest conversion of DBT into HBP in the shortest operation time with the lowest possible amount of biomass for each tested combination of 5 and $23 \mathrm{~h}$ cells.

\section{Results and discussion}

Although the employed cells of Pseudomonas putida CECT 5279 collected at $9 \mathrm{~h}$ of growth time in resting cell assays showed the highest capability for desulfurization [1], the formulation of complex biocatalysts by combining cells of 5 and $23 \mathrm{~h}$ of growth time is suggested to offer better features due to the higher activities offered for desulfinase and monooxygenase enzymes, respectively. In order to determine an optimized formulation of complex biocatalyst, cells collected at 5 and $23 \mathrm{~h}$ were combined in different proportions as well as varying total biomass concentration. The results obtained using the aforementioned proposed biocatalysts were compared to the responses shown by $9 \mathrm{~h}$ cells when analogous total biomass concentrations are employed.

According to this, the experimental planning for this study of the complex biocatalyst and its comparison to the simple catalyst is shown in Table 1 . This first table classifies each run according to the total biomass concentration used, $C_{X}$, the $23 \mathrm{~h}$ cell biomass fraction, $\mathrm{Y}^{23}$ (as shown in Eq. (5)) and the growth time, $t_{\mathrm{G}}$, for cells employed in each experiment. In all cases, $25 \mu \mathrm{M}$ DBT was utilized as initial sulfur model compound concentration. The other operational variables were maintained at a constant value, as mentioned in the BDS assay description.

In Figs. 1-4, values of $X_{\mathrm{BDS}}^{\mathrm{MAX}}, t_{\mathrm{BDS}} \mathrm{MAX}, R_{\mathrm{DBT}}^{0}$ and $P_{\mathrm{BDS}}^{\mathrm{MAX}}$, respectively, for each tested total biomass concentration from 0.7 to $4.2 \mathrm{gDCW} / \mathrm{L}$, are shown for both $9 \mathrm{~h}$ simple biocatalysts and a 5 and $23 \mathrm{~h}$ complex biocatalysts. When using complex biocatalysts, in order to highlight the relative composition of 5 and $23 \mathrm{~h}$, variable $\mathrm{Y}^{23}, 23 \mathrm{~h}$ cell biomass fraction, is employed. $\mathrm{Y}^{23}$ shows the proportion of $23 \mathrm{~h}$ cell in the complex biocatalyst as shown by the following equation:

$\mathrm{Y}^{23}=\frac{C_{X}^{23}}{C_{X}^{5+23}}$

In Fig. 5, values of specific conversion rate are represented for both $9 \mathrm{~h}$ simple catalysts and each 5 and $23 \mathrm{~h}$ biocatalyst proposed. Total biomass concentration and $23 \mathrm{~h}$ cell biomass fraction are the variables considered in this study.

Fig. 1 depicts a progressive increase in maximum percentage of biodesulfurization when higher biomass concentrations of $9 \mathrm{~h}$ cells are employed. Complete transformation of DBT into HBP is achieved when biomass concentrations higher than $2.1 \mathrm{gDCW} / \mathrm{L}$ are used. In

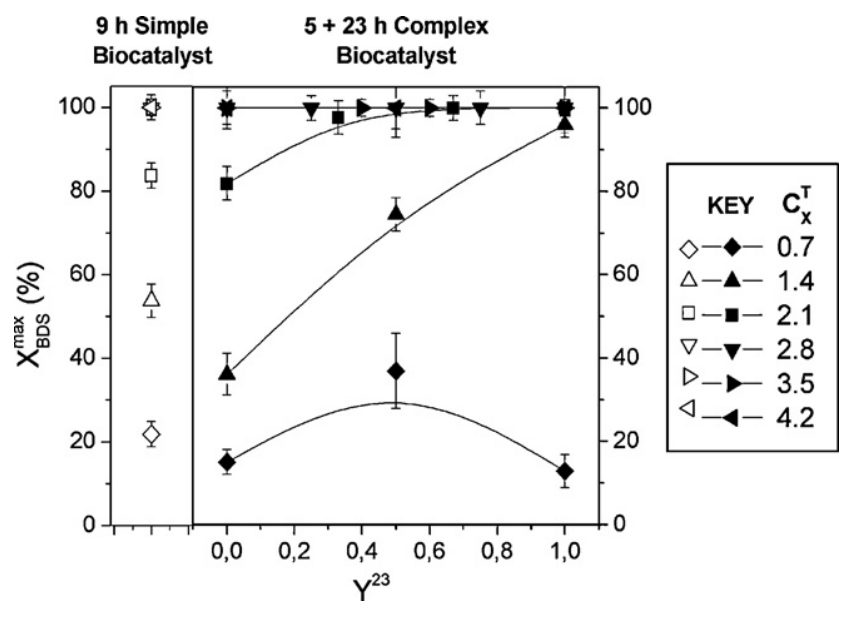

Fig. 1. Comparison of the values of $X_{\mathrm{BDS}}^{\mathrm{MAX}}$ between a $9 \mathrm{~h}$ simple biocatalyst and different 5 and $23 \mathrm{~h}$ complex biocatalysts, employing total biomass concentrations between 0.7 and $4.2 \mathrm{gDCW} / \mathrm{L}$.

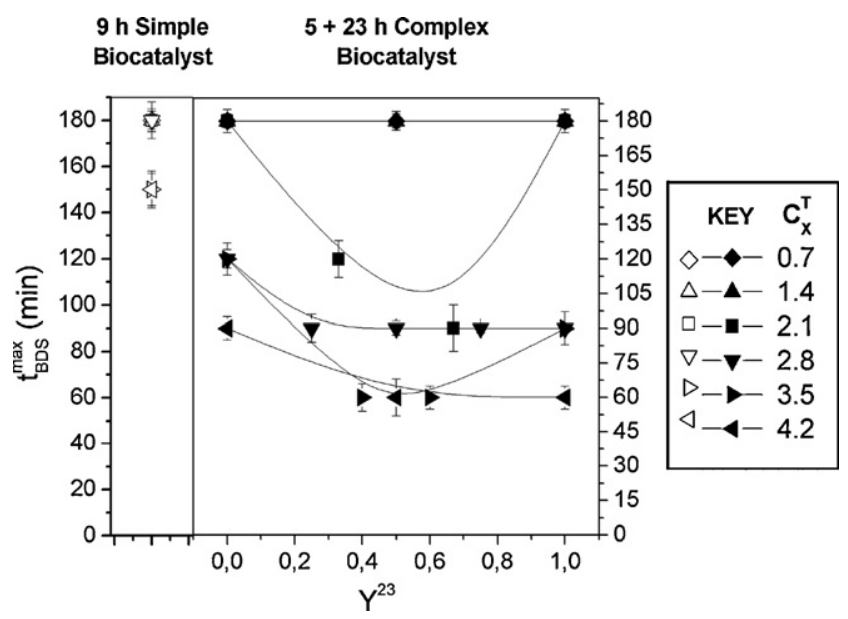

Fig. 2. Comparison of the values of $t_{\mathrm{BDS}}$ between a $9 \mathrm{~h}$ simple biocatalyst and different 5 and $23 \mathrm{~h}$ complex biocatalysts, employing total biomass concentrations from 0.7 to $4.2 \mathrm{gDCW} / \mathrm{L}$.

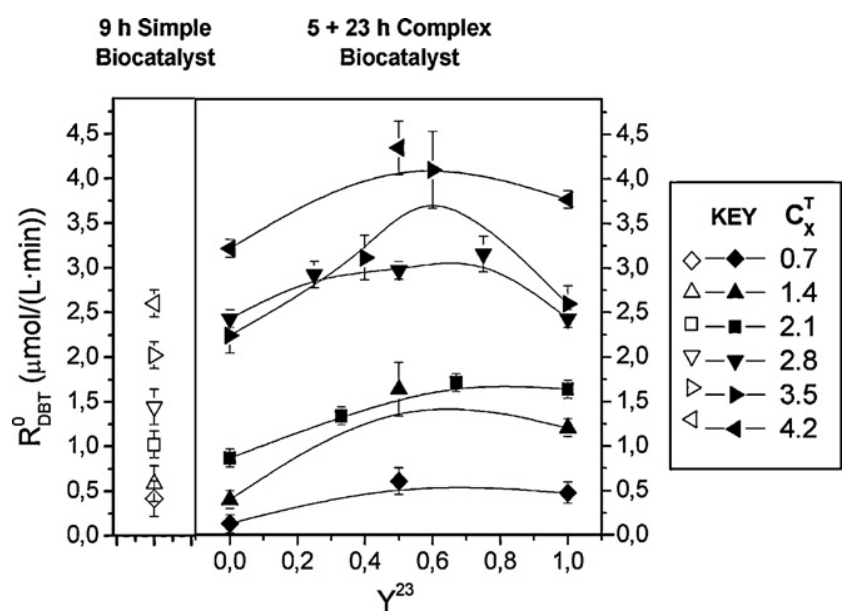

Fig. 3. Comparison of the values of $R_{\mathrm{DBT}}^{0}$ between a $9 \mathrm{~h}$ simple biocatalyst and different 5 and $23 \mathrm{~h}$ complex biocatalysts, employing total biomass concentrations between 0.7 and $4.2 \mathrm{gDCW} / \mathrm{L}$. 
Table 1

Experimental schedule involving as variables the total biomass concentration $\left(C_{X}^{T}\right)$, mass proportion of $23 \mathrm{~h}$ cells in the complex biocatalyst $\left(\mathrm{Y}^{23}\right)$ and growth time $\left(t_{\mathrm{G}}\right)$.

\begin{tabular}{|c|c|c|c|c|}
\hline Run & Kind of biocatalyst & $C_{X}^{T}(\mathrm{gDCW} / \mathrm{L})$ & $\mathrm{Y}^{23}$ & $t_{\mathrm{G}}(\mathrm{h})$ \\
\hline 1 & Simple & 0.7 & - & 9 \\
\hline 2 & Complex & 0.7 & 0.00 & $5+23$ \\
\hline 3 & Complex & 0.7 & 0.50 & $5+23$ \\
\hline 4 & Complex & 0.7 & 1.00 & $5+23$ \\
\hline 5 & Simple & 1.4 & - & 9 \\
\hline 6 & Complex & 1.4 & 0.00 & $5+23$ \\
\hline 7 & Complex & 1.4 & 0.50 & $5+23$ \\
\hline 8 & Complex & 1.4 & 1.00 & $5+23$ \\
\hline 9 & Simple & 2.1 & - & 9 \\
\hline 10 & Complex & 2.1 & 0.00 & $5+23$ \\
\hline 11 & Complex & 2.1 & 0.33 & $5+23$ \\
\hline 12 & Complex & 2.1 & 0.67 & $5+23$ \\
\hline 13 & Complex & 2.1 & 1.00 & $5+23$ \\
\hline 14 & Simple & 2.8 & - & 9 \\
\hline 15 & Complex & 2.8 & 0.00 & $5+23$ \\
\hline 16 & Complex & 2.8 & 0.25 & $5+23$ \\
\hline 17 & Complex & 2.8 & 0.50 & $5+23$ \\
\hline 18 & Complex & 2.8 & 0.75 & $5+23$ \\
\hline 19 & Complex & 2.8 & 1.00 & $5+23$ \\
\hline 20 & Simple & 3.5 & - & 9 \\
\hline 21 & Complex & 3.5 & 0.00 & $5+23$ \\
\hline 22 & Complex & 3.5 & 0.40 & $5+23$ \\
\hline 23 & Complex & 3.5 & 0.60 & $5+23$ \\
\hline 24 & Complex & 3.5 & 1.00 & $5+23$ \\
\hline 25 & Simple & 4.2 & - & 9 \\
\hline 26 & Complex & 4.2 & 0.00 & $5+23$ \\
\hline 27 & Complex & 4.2 & 0.50 & $5+23$ \\
\hline 28 & Complex & 4.2 & 1.00 & $5+23$ \\
\hline
\end{tabular}

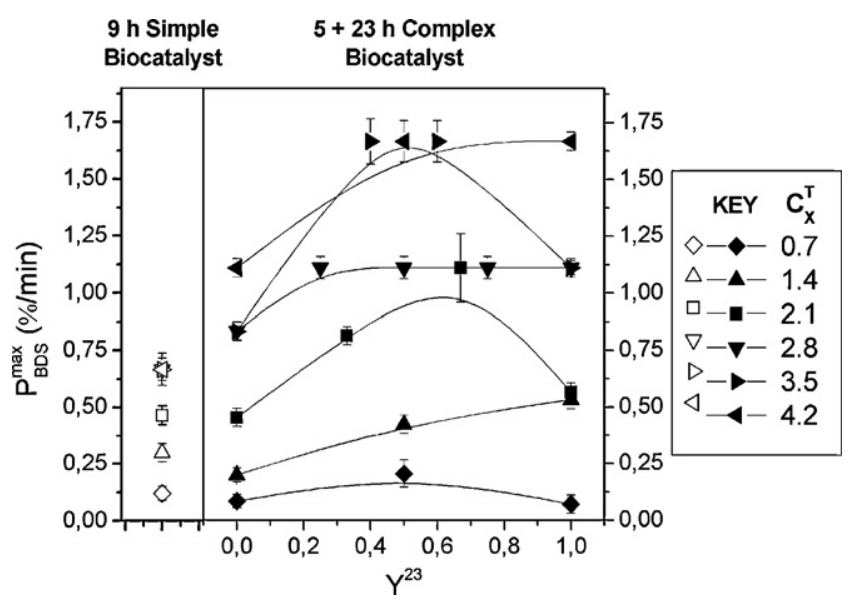

Fig. 4. Comparison of the values of $P_{\mathrm{BDS}}^{\mathrm{MAX}}$ between a $9 \mathrm{~h}$ simple biocatalyst and different 5 and $23 \mathrm{~h}$ complex biocatalysts, employing total biomass concentrations from 0.7 to $4.2 \mathrm{gDCW} / \mathrm{L}$.

the case of employing cells collected at 5 and $23 \mathrm{~h}$ of growth time, an analogous behavior is observed when total biomass concentration is raised. However, a higher percentage of biodesulfurization is achieved when the two cell qualities are combined $\left(0<\mathrm{Y}^{23}<1\right)$ than when using a simple biocatalyst consisting of cells of $9 \mathrm{~h}$ of growth time. According to this, neither a biocatalyst formed only by $5 \mathrm{~h}$ cells $\left(\mathrm{Y}^{23}=0\right)$ nor a biocatalyst composed only by $23 \mathrm{~h}$ cells $\left(\mathrm{Y}^{23}=1\right)$ offer better properties than a $9 \mathrm{~h}$ biocatalyst, when a total biomass concentration of $0.7 \mathrm{gDCW} / \mathrm{L}$ is employed. However, due to the combination of high desulfinase activity in $5 \mathrm{~h}$ cells and high monooxygenase activity in $23 \mathrm{~h}$ cells [1,2], the complex biocatalyst that combines these two kind of cells $\left(\mathrm{Y}^{23}=0.5\right)$ achieve better behavior for BDS than the $9 \mathrm{~h}$ simple biocatalyst. That leads to a higher DBT conversion into HBP in the same time (180 min), and higher initial DBT removal rate and maximum productivity, as well. The employ of higher biomass concentrations shows the impor-

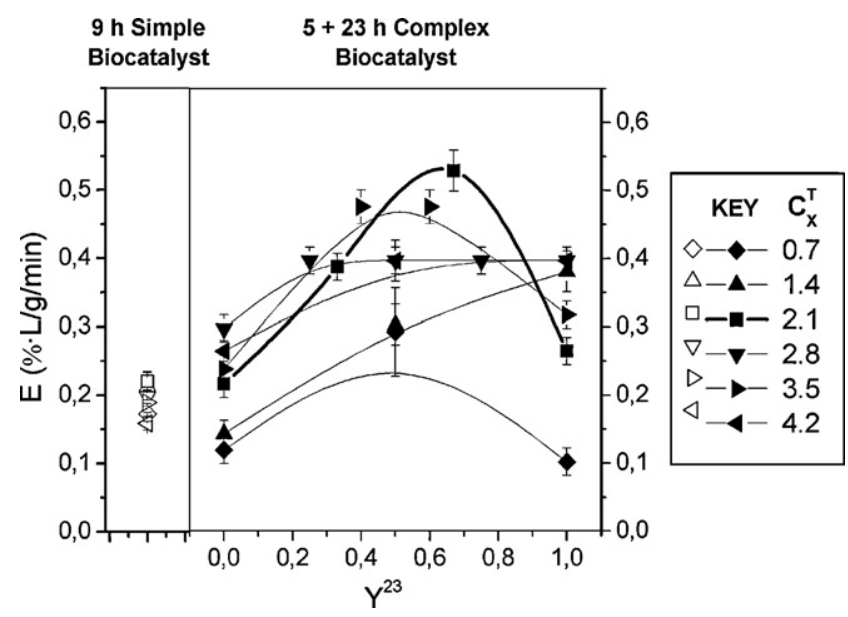

Fig. 5. Values of the specific conversion rate, $E$, for the different proposed 5 and $23 \mathrm{~h}$ complex biocatalysts varying total biomass concentration and the proportion of cells from each age.

tant contribution of $23 \mathrm{~h}$ cells to DBT removal. Despite the fact that this growth time presents a low desulfinase activity [1], increasing biomass concentration allows compensating this situation so that total DBT conversion into HBP is reached.

In Fig. 2 needed times for maximum desulfurization, $t_{\mathrm{BDS}} \mathrm{MAX}$, are presented for both simple and complex biocatalysts. The employ of simple biocatalysts only allows a light reduction in time when biomass concentrations higher than $2.8 \mathrm{gDCW} / \mathrm{L}$ are employed. In contrast, most combinations of 5 and $23 \mathrm{~h}$ cells constituting complex biocatalysts allow reducing needed time below $120 \mathrm{~min}$. The combination of desulfinate activity in cells collected at $5 \mathrm{~h}$ of growth time and monooxygenase activities in $23 \mathrm{~h}$ cells, leads to the smallest needed times up to $60 \mathrm{~min}$, as can be seen in the mentioned figure (at biomass total concentration higher than $2.8 \mathrm{~g} / \mathrm{L}$ ).

Similarly, Fig. 3 shows values obtained for initial DBT removal rate. There is an important improvement in DBT elimination when 5 and $23 \mathrm{~h}$ cells are combined in comparison with the employ of $9 \mathrm{~h}$ cells. Although biocatalysts formulated either only using $5 \mathrm{~h}$ cells or only $23 \mathrm{~h}$ cells cannot improve results from a simple biocatalyst when the lowest biomass concentration is employed $(0.7 \mathrm{gDCW} / \mathrm{L})$, the increase of cell concentration in a complex biocatalyst offers much better results than the ones obtained with a $9 \mathrm{~h}$ biocatalyst. Furthermore, Fig. 3 shows the advantages of combining two cell ages from the point of view of DBT removal rate, due to the mentioned desulfinase and monooxygenase activities working together. Therefore, the best $R_{\mathrm{DBT}}^{0}$ values are obtained when $\mathrm{Y}^{23}$ ratios between 0 and 1 are employed.

Maximum productivity values are presented in Fig. 4 for both simple and complex biocatalysts. It is important to emphasize that combination of 5 and $23 \mathrm{~h}$ cells achieve much better results in all cases than the employ of a $9 \mathrm{~h}$ simple biocatalyst. In the latter case, increasing biomass concentration over $2.8 \mathrm{gDCW} / \mathrm{L}$ does not yield better results. However, combining high desulfinase activity of $5 \mathrm{~h}$ cells and high monooxygenase activities of $23 \mathrm{~h}$ cells offer the highest productivity values for each tested total biomass concentration. When only cells collected at $23 \mathrm{~h}$ of growth time are employed with the higher biomass concentration, high maximum productivity is maintained according to their low but even important desulfinase activity, which is compensated with the use of a high cell concentration. These different behaviors observed demonstrate the advantage of suitably exploiting the skills of 5 and $23 \mathrm{~h}$ cells in order to follow the different steps of the $4 \mathrm{~S}$ pathway. The combination of cells with different predominant enzyme activities allows higher productivities than those where cells of a single growth time are used. 
Table 2

Comparison between a $9 \mathrm{~h}$ biocatalyst and the selected complex biocatalyst.

\begin{tabular}{lcc}
\hline & $\begin{array}{l}9 \text { h simple biocatalyst } \\
C_{X}=2.1 \mathrm{~g} / \mathrm{L}\end{array}$ & $\begin{array}{l}5+23 \text { h complex biocatalyst } \\
\mathrm{Y}^{23}=0.67 ; C_{X}^{T}=2.1 \mathrm{~g} / \mathrm{L}\end{array}$ \\
\hline$X_{\mathrm{BDS}}^{\mathrm{MAX}}(\%)$ & 83.6 & 100.0 \\
$t_{\mathrm{BDS} \text { max }}(\min )$ & 180 & 90 \\
$R_{\mathrm{DBT}}^{0}(\mu \mathrm{mol} /(\mathrm{L} \min ))$ & 1.022 & 1.714 \\
$P_{\mathrm{BDS}}^{\mathrm{MAX}}(\% / \mathrm{min})$ & 0.465 & 1.111 \\
$\mathrm{E}(\% \mathrm{~L} /(\mathrm{g} \min ))$ & 0.221 & 0.530 \\
\hline
\end{tabular}

As can be seen in Fig. 5, where values of specific conversion rate are represented for both $9 \mathrm{~h}$ simple biocatalysts and each 5 and $23 \mathrm{~h}$ biocatalyst proposed, this parameter is much larger when a complex biocatalyst is employed. From all the tested formulations, using both 5 and $23 \mathrm{~h}$ cells, one cell combination stands out among the rest. A complex biocatalyst formulated with a $1: 2$ ratio of 5 and $23 \mathrm{~h}$ cells $\left(\mathrm{Y}^{23}=0.67\right)$ and a total biomass concentration of $2.1 \mathrm{gDCW} / \mathrm{L}$, offers a complete DBT conversion in a reduced time with an acceptable concentration of invested biomass. Table 2 compares the parameter values obtained when the most active cell age for desulfurization [1] is employed in a simple biocatalyst to those when the selected formulation of a 5 and $23 \mathrm{~h}$ complex biocatalyst is used. Although $9 \mathrm{~h}$ simple biocatalyst achieves a high DBT conversion (ca. 84\%), the selected complex biocatalyst allows complete transformation of DBT into HBP. Moreover, the time needed by 5 and $23 \mathrm{~h}$ cell biocatalyst in order to reach this value is doubled by the time needed by the $9 \mathrm{~h}$ cell for a lower percentage of desulfurization. Reached $R_{\mathrm{DBT}}^{0}$ and $P_{\mathrm{BDS}}^{\mathrm{MAX}}$ values are particularly higher in the complex biocatalyst than in the simple one.

\section{Conclusions}

The desulfurizating properties of complex biocatalysts composed by 5 and $23 \mathrm{~h}$ cells has been shown according to the respective desulfinase and monooxygenase activities contributed to the mixture [1]. The highest percentage of desulfurization, initial DBT removal rate and the lower time of desulfurization needed support this fact. The mixture composed by a 1:2 ratio of cells collected at 5 and $23 \mathrm{~h}$ of growth time of Pseudomonas putida CECT 5279 , using a total biomass concentration of $2.1 \mathrm{gDCW} / \mathrm{L}$ showed the best capabilities for desulfurization in resting cells, among all the proposed biocatalyst formulations, according to the specific conversion rate, previously defined. Improving complex biocatalysts can offer better biodesulfurization processes, achieving higher DBT conversions and reducing time needed for biodesulfurization.

\section{Acknowledgements}

This work has been supported by Plan Nacional de I+D, under contract CTQ2007-60919/PPQ and by UCM and BSCH (research team no. 910134). The grant awarded to one of the authors (J. Calzada) by the Ministerio de Educacion y Ciencia, co-funded with European Social Fund, is gratefully recognized.

\section{Appendix A. Nomenclature}

$\begin{array}{ll}\text { BDS } & \text { biodesulfurization } \\ C_{j} & \text { concentration of compound } j(\mu \mathrm{M}) \\ C_{X}^{i} & \begin{array}{l}\text { concentration of biomass }(\mathrm{gDCW} / \mathrm{L}) \text {, total or at } i \text { growth } \\ \text { time }\end{array} \\ \text { DBT } & \text { dibezothiophene } \\ \text { DBTO } & \text { dibenzothiophene-5-oxide } \\ \text { DBTO }_{2} & \text { dibenzothiophene-5,5-dioxide }\end{array}$

E specific conversion rate $((\% \mathrm{~L}) /(\min \mathrm{gDCW}))$

HBPS 2-(2-hydroxybiphenyl)-benzenesulfinate

HBP 2-hydroxybiphenyl

HDS hydrodesulfurization

IPTG isopropyl- $\beta$-D-galactopyranoside

Mtoe millions of tons of oil equivalents

$P_{\mathrm{BDS}}^{\mathrm{MAX}} \quad$ maximum biodesulfurization productivity

$R_{\mathrm{DBT}}^{0} \quad$ initial DBT removal rate

$t_{\mathrm{BDS}}$ max time for maximum biodesulfurization (min)

$t_{\mathrm{G}} \quad$ growth time $(\mathrm{h})$

$X_{\mathrm{BDS}} \quad$ percentage of biodesulfurization (\% BDS)

$\mathrm{Y}^{23}$ mass proportion of $23 \mathrm{~h}$ cells in the complex biocatalyst

\section{Subindexes}

DBT refers to dibezothiophene

HBP refers to 2-hydroxybiphenyl

$X \quad$ refers to biomass

\begin{tabular}{|c|c|}
\hline Superi & exes \\
\hline 0 & refers to initial time \\
\hline 5 & refers to $5 \mathrm{~h}$ growth cell time \\
\hline $5+23$ & refers to both 5 and $23 \mathrm{~h}$ growth cell time \\
\hline 9 & refers to $9 \mathrm{~h}$ growth cell time \\
\hline 23 & refers to $23 \mathrm{~h}$ growth cell time \\
\hline MAX & refers to maximum value \\
\hline & refers to the total amount of cells \\
\hline
\end{tabular}

\section{References}

[1] Calzada J, Zamarro MT, Alcon A, Santos VE, Diaz E, Garcia JL, Garcia-Ochoa F. Analysis of dibenzothiophene desulfurization in a recombinant Pseudomonas putida strain. Appl Environ Microbiol 2009;75:875-7.

[2] Calzada J, Heras S, Alcon A, Santos VE, García-Ochoa F. Biodesulfurization of dibenzothiophene using Pseudomonas putida CECT 5279: a biocatalyst formulation comparison. Energy Fuels 2009;23(11):5491-5.

[3] International Energy Agency. Key World Energy Statistics. Paris: OECD/IEA; 2009.

[4] British Petroleum. BP statistical review of world energy. London: BP p.I.C; 2007.

[5] Soleimani M, Bassi A, Margaritis A. Biodesulfurization of refractory organic sulfur compounds in fossil fuels. Biotechnol Adv 2007;25:570-96.

[6] Ansell GP, Golunski SE, Hatcheer HA, Rajaram RR. Effects of $\mathrm{SO}_{2}$ on the alkane activity. Catal Lett 1991:11:183-90.

[7] Yu TC, Shaw H. The effect of sulfur poisoning on methane oxidation over palladium supported on $\gamma$-alumina catalysts. Appl Catal B: Environ 1998;18:105-14.

[8] European Directive 2003/17/EC of the European Parliament and of the Council of 3 March 2003 amending Directive 98/70/EC relating to the quality of petrol and diesel fuels. OJ L76; 22.3.2003. p. 10.

[9] Kilbane JJ. Microbial biocatalyst developments to upgrade fossil fuels. Curr Opin Microbiol 2006;17:1-10.

[10] Babich IV, Moulijn JA. Science and technology of novel processes for deep desulfurization of oil refinery streams: a review. Fuel 2003;82:607-31.

[11] Monticello DJ. Riding the fosil fuel biodesulfurization wave. Chemtech 1998:38-45.

[12] Monticello DJ, Finnerty WR. Microbial desulfurization of fossil fuels. Ann Rev Microbiol 1985;39:371-89.

[13] Setti L, Lazarini G, Pifferi PG. Whole cell biocatalysis for an oil desulfurization. Fuel Process Technol 1997;52:145-53.

[14] Ransom I, Rivas AC. Biocatalizador para remover azufre orgánico en hidrocarburos. Visión Tecnol 1999; 7:15-22.

[15] Le Borge S, Quintero R. Review biotechnological processes for the refining of petroleum. Fuel Process Technol 2003;81:155-69.

[16] Gupta N, Roychoudhury PK, Deb JK. Biotechnology of desulfurization of diesel: prospects and challenges. Appl Microbiol Biotechnol 2005;66:356-66.

[17] Linguist L, Pacheco MA. Enzyme-based diesel desulfurization process offers energy, $\mathrm{CO}_{2}$ advantages. Oil Gas J 1997;97:45-8.

[18] Pacheco MA, Lange EA, Pienkos PT, Yu LQ, Rouse MP, Lin Q, Linguist L. Recent advances in biodesulfurizatio of diesel fuel. In: Annual Meeting, National Petrochemical and Refiners Association. 1999.

[19] Monticello DJ. Biodesulfurization and the upgrading of petroleum distillates. Curr Opin Biotechnol 2000;11:540-6.

[20] Kayser KJ, Bielaga-Jones BA, Jackowski K, Odusan O, Kilbane JJ. Isolation and characterization of a moderate thermophile, Mycobacterium phlei GTIS10, capable of dibenzothiophene desulfurization. J Gen Microbiol 1993;139:3123-9.

[21] Ohshiro T, Izumi Y. Review Microbial desulfurization of organic compounds in petroleum. Biosci Biotechnol Biochem 1999;63:1-9.

[22] Denome SA, Oldfield C, Nash LJ, Young KD. Characterization of the desulfurization genes from Rhodococcus sp. strain IGTS8. J Bacteriol 1994;176:6707-16. 
[23] del Olmo C, Santos VE, Alcon A, Garcia-Ochoa F. Production of a Rhodococcus erythropolis IGTS8 biocatalyst for DBT biodesulfurization: influence of operational conditions. Biochem Eng J 2005;22:229-37.

[24] del Olmo C, Alcon A, Santos VE, Garcia-Ochoa F. Modeling the production of a Rhodococcus erythropolis IGTS8 biocatalyst for DBT biodesulfurization: influence of media composition. Enzyme Microb Technol 2005;37:157-66.

[25] Oldfield C, Pogrebinsky O, Simmonds J, Olson ES, Kulpa CF. Elucidation of the metabolic pathway for dibenzothiophene desulfurization by Rhodococcus $s p$. strain IGTS8 (ATCC 53968). Microbiology 1997;143:2961-73.

[26] Ohshiro T, Izumi Y. Purification, characterization and crystallization of enzymes for dibenzothiophene desulfurization. Bioseparation 2000:9:185-8.

[27] Kertesz MA, Wirtek C. Desulfurization and desulfonation: applications of sulfur-controlled gene expression in bacteria. Appl Microbiol Biotechnol 2001;57:460-6.

[28] Kropp KG, Fedorak PM. A review of the occurrence, toxicity, and biodegradation of condensed thiophenes found in petroleum. Can J Microbiol 1998;44:605-22.

[29] McFarland B. Biodesulfurization. Curr Opin Microbiol 1999;2:257-64.

[30] Denome SA, Olson ES, Young KD. Identification and cloning of genes involved in specific desulfurization of dibenzothiophene by Rhodococcus sp. strain IGTS8. Appl Environ Microbiol 1993;59:2837-43.

31] Lee WC, Ohshiro T, Matsubara T, Izumi Y, Tanokura M. Crystal structure and desulfurization mechanism of 2-hydroxybiphenyl-2-sulfinic acid desulfinase. J Biol Chem 2006;281:32534-9.

[32] Van Hamme JD, Singh A, Ward OP. Recent advances in petroleum microbiology. Microbiol Mol Biol Rev 2003:67:503-49.

[33] Xu P, Yu B, Li FL, Cai XF, Ma CQ. Microbial degradation of sulfur, nitrogen and oxygen heterocycles. Trends Microbiol 2006;14:398-405.

[34] Omori H, Saiki Y, Kasuga K, Kodama T. Desulfuration of alkyl and aromatic sulfides an sulfonates by dibenzpthiophene desulfurizing Rhodococcus sp. strain SY1. Biosci Biotechnol Biochem 1995;59:1195-8.

[35] Hirasawa K, Ishii Y, Kobayashi M, Koizumi K, Maruhashi K. Improvement of desulfurization activity in Rhodococcus erythropolis KA2-5-1 by genetic engineering. Biosci Biotechnol Biochem 2001;65:239-46.

[36] Piddington CS, Kovacevich BR, Rambosek J. Sequence and molecular characterization of a DNA region encoding the dibenzothiophene desulfurization operon of Rhodococcus sp. strain IGTS8. Appl Environ Microbiol 1995;61:468-75.

[37] Denis-Larose C, Labbe D, Bergeron H, Jones AM, Greer CW, Al-Hawari J, Grossman MJ, Sankey BM, Lau PCK. Conservation of plasmid-encoded dibenzothiophene desulfurization genes in several Rhodococci. Appl Environ Microbiol 1997;63:2915-9.
[38] Gallardo ME, Ferrández A de Lorenzo V, Garcia JL, Diaz E. Designing recombinant Pseudomonas strains to enhance biodesulfurization. J Bacteriol 1997;179:7156-60.

[39] Watanabe K, Noda KI, Ohta Y, Maruhashi K. Desulfurization of light gas oil by a novel recombinant strain from Pseudomonas aeruginosa. Biotechnol Lett 2002;24:897-903.

[40] Tao F, Yu B, Xu P, Ma CQ. Biodesulfurization in biphasic systems containing organic solvents. Appl Environ Microbiol 2006;72:4604-9.

[41] Noda KI, Watanabe K, Maruhashi K. Recombinant Pseudomonas putida carrying both the dsz and hcu genes can desulfurize dibenzothiophene in n-tetradecane. Biotechnol Lett 2003;25:1147-50.

[42] Noda KI, Watanabe K, Maruhashi K. Isolation of a recombinant desulfurizing 4,6-dipropyl dibenzothiophene in n-tetradecane. J Biosci Bioeng 2003;95:354-60

[43] Watanabe K, Noda KI, Konishi J, Maruhashi K. Desulfurization of 2,4,6,8 tetraethyl dibenzothiophene by recombinant Mycobacterium sp. strain MR65. Biotechnol Lett 2003;25:1451-6.

[44] Watanabe K, Noda KI, Maruhashi K. Enhanced desulfurization in transposon-mutant strain of Rhodococcus erythropolis. Biotechnol Lett 2003;25: 1299-304.

[45] Ma T, Li G, Li J, Liang F, Liu R. Desulfurization of dibenzothiophene by Bacillus subtilis recombinants carrying dszABC and dszD genes. Biotechnol Lett 2006;28:1095-100.

[46] Galan B, Diaz E, Garcia JL. Enhancing desulfurization by engineering a flavin reductase-encoding gene cassette in recombinant biocatalysts. Environ Microbiol 2000;2:687-94.

[47] Galan B, Diaz E, Ferrández A, Prieto MA, Garcia JL, Garcia-Ochoa L, Garcia-Calvo E. International Patent WO01/70996 AL; 2001.

[48] Martin AB, Alcon A, Santos VE, Garcia-Ochoa F. Production of a biocatalyst of Pseudomonas putida CECT5279 for dibenzothiophene (DBT) biodesulfurization for different media compositions. Energy Fuels 2004;18:851-7.

[49] Martin AB, Alcon A, Santos VE, Garcia-Ochoa F. Production of a biocatalyst of Pseudomonas putida CECT5279 for DBT biodesulfurization: influence of the operational conditions. Energy Fuels 2005;19:775-82.

[50] Alcon A, Santos VE, Martin AB, Yustos P, Garcia-Ochoa F. Biodesulfurisation of DBT with Pseudomonas putida CECT5279 by resting cells: Influence of cell growth time on reducing equivalent concentration and $\mathrm{HpaC}$ activity. Biochem Eng J 2005;26:168-75. 